\title{
Toll-Like Receptor 1
}

National Cancer Institute

\section{Source}

National Cancer Institute. Toll-Like Receptor 1. NCI Thesaurus. Code C30101.

Toll-like receptor 1 (786 aa, $90 \mathrm{kDa}$ ) is encoded by the human TLR1 gene. This protein plays a role in antimicrobial immune responses. 